\title{
THE ACCOUNTING TREATMENT OF CREDIT CARD REWARDS PROGRAMMES: A SOUTH AFRICAN PERSPECTIVE (PART I)
}

\author{
Sophia Brink* \\ Stellenbosch University
}

Received: May 2015

Accepted: July 2016

\begin{abstract}
Credit card rewards programmes are a common phenomenon in the South African market. On 1 July 2007 the International Accounting Standards Board (IASB) issued IFRIC 13 Customer Loyalty Programmes to give specific guidance to suppliers on the accounting treatment of customer loyalty programme transactions. Although credit card rewards programmes are specifically included in the scope of this Interpretation, in practice not all credit card rewards programmes currently account for award credits under the revenue deferral model (IFRIC 13). During May 2014 the IASB and the United States Financial Accounting Standards Board (FASB) published IFRS 15 Revenue from Contracts with Customers intended to replace six existing Standards and Interpretations, including IFRIC 13. Currently there is uncertainty whether or not a credit card rewards programme transaction falls within the scope of IFRS 15. Despite concerns raised the Boards decided against providing any additional guidance to credit card rewards programmes and indicated that they leave it up to management's judgement to determine how to account for these transactions. The main objective of the research reported in this article was to develop and recommend an industry practice for the accounting treatment of South African credit card rewards programme transactions by reconciling the viewpoints of these rewards programmes in South Africa. This will prevent inconsistencies in accounting for credit card rewards programme transactions in South Africa.
\end{abstract}

Keywords

Award credits, customer in relation to the card issuer, IFRIC 13, IFRS 15.

*Ms SM Brink is a senior lecturer in the School of Accounting, Stellenbosch University, Stellenbosch, South Africa. [*****] 


\section{BACKGROUND AND FORMULATION OF THE STUDY}

\subsection{Background}

Most credit card issuers offer their cardholders participation in a customer loyalty programme (Conradie, 2007:29). The main aim of a credit card rewards programme is to encourage credit cardholders to use just one credit card to make their purchases (Creditor Web, 2014). Credit card rewards programmes offer their members direct cash back or award credits (points or miles) that can be used to purchase goods and services in exchange for using their credit card (Buchi, 2014). Award credits are mainly earned for each credit card transaction, but some programmes also offer additional rewards for credit card purchases from any of the rewards programme partners. A credit card rewards programme differs from other customer loyalty programmes in that it awards a payment mechanism rather than the acquisition of goods or services from a qualifying supplier (Conradie \& Goldstuck, 2003:8).

The first South African credit card rewards programme was launched in 1995 (Conradie, 2007:20) and currently 13 financial institutions are making use of credit card rewards programmes in South Africa (Siddle, 2014). eBucks, the First National Bank credit card rewards programme, made eBucks allocations to the value of R500 million (Kearney, 2013) and R723 million (Firstrand Group, 2013:38) during the 2012 and 2013 financial years respectively. During 2012 ABSA Rewards clocked up one million rewards members. By that time it had paid out more than R300 million in cash rewards since the rewards programme was launched in 2009. Given the popularity of credit card rewards programmes in South Africa, together with the extremely high rand value associated with it, it is important to correctly account for credit card rewards programme transactions for accounting purposes.

In order to understand the accounting treatment of customer loyalty programmes one must consider International Accounting Standards prescribing rules on how to account for these transactions. During May 2014, the International Accounting Standards Board (IASB), together with the United States Financial Accounting Standards Board (FASB), published International Financial Reporting Standards (IFRS) 15 Revenue from Contracts with Customers to streamline accounting for revenue across all industries and to correct inconsistencies in existing Standards and practices (Lamoreaux, 2012:30). The IASB and FASB initiated this joint project to clarify the revenue recognition principles and to develop a common revenue Standard for IFRS and the United States Generally Accepted Accounting Practices (US GAAP) (IFRS 15, par. IN4). Therefore, IFRS 15 is intended to supersede virtually all existing revenue Standards and Interpretations under IFRS and US GAAP (Deloitte, 2012:1; Ernst \& Young, 2012:2) including IFRIC 13 Customer Loyalty Programmes (KPMG, 2011:4). On 1 July 2007, the IASB issued IFRIC 13 (the Interpretation of International Financial Reporting Interpretation Committee 13) to give specific guidance to suppliers on the accounting treatment of customer loyalty programme transactions. This Interpretation has been applied by suppliers with annual periods beginning on or after 1 July 2008 and will be withdrawn for annual reporting periods beginning on or after 1 January 2017, when IFRS 15 becomes effective.

The process of compiling the new revenue Standard started in 2010 with the issue of $\varepsilon D / 2010 / 6$ Revenue from Contracts with Customers and, based on comments received, significant changes were made to the proposed revenue model. The exposure draft (Exposure Draft ED/2011/6 Revenue from Contracts with (ustomers) was issued for a second time during November 2011. Deliberations on the second exposure draft continued throughout 2012 and 2013 with substantial 
re-deliberations during the first two quarters of 2014 (IASB, 2014). IFRS 15 will be effective for annual reporting periods beginning on or after 1 January 2017 (IFRS 15, par. Cl) and will be applied retrospectively for all periods presented in the period of adoption with only limited reliefs.

\subsection{Research problem}

In response to the second exposure $\operatorname{draft}(\varepsilon D / 2011 / 6)$, the FASB and IASB received approximately 360 comment letters (PricewaterhouseCoopers, 2012:1). Many of these comment letters were received from customer loyalty programme suppliers and more specifically from financial services loyalty programmes (credit card rewards programmes) (KPMG, 2013). Based on the lack of specific guidance for customer loyalty programmes in the $\varepsilon D / 2011 / 6$, with only one reference to 'customer award credits (points)' (in the Application Guidance paragraph B20) in the entire 89 page document, these comments were understandable and in a way expected. The illustrative examples that accompany the $\varepsilon D / 2011 / 6$ also include only one example that specifically applies to customer loyalty programme transactions (vs. the two illustrative examples that accompany IFRIC 13).

The main concern raised by respondents from credit card rewards programmes was whether or not all credit card rewards programme transactions are included in the scope of the new revenue Standard (PricewaterhouseCoopers, 2012:15). The scope of IFRS 15 (paragraph 6) states that an entity shall apply IFRS 15 to a contract only if the counterparty to the contract is a customer (without any amendments from $\varepsilon D / 2011 / 6$ paragraph 10 ). Therefore, in a credit card rewards programme transaction the customer in relation to the card issuer determines whether or not the transaction falls within the scope of IFRS 15 or not. There are two alternatives:

- If the merchant is identified as the customer in relation to the card issuer in the transaction the transaction falls outside of the scope of IFRS 15.

- If the cardholder (member of the rewards programme) is identified as the customer in relation to the card issuer in the transaction the transaction falls within the scope of IFRS 15.

It is therefore possible that some credit card rewards programmes fall within the scope of IFRS 15 and some outside the scope. The Boards (IASB and FASB) observed that credit card arrangements are complex and the facts will vary among the different programmes. Despite the concerns raised about a lack of guidance, the Boards decided against specifically addressing credit card rewards programmes in IFRS 15 (Ernst \& Young, 2013). The Boards also decided that it would not be feasible to further define a customer for the purposes of applying IFRS 15 (FASB \& IASB, 2013:12). IFRS 15 therefore does not include any additional guidance, application guidance or examples for different facts and circumstances in a credit card rewards programme. The Boards advised credit card rewards programmes to consider all the facts and circumstances when accounting for credit card reward programmes, given the unique and varied nature of these agreements (Ernst \& young, 2013:2). When there is a lack of guidance in IFRS, different industry practices might develop. An entity will typically adopt a specific accounting policy and apply that policy when accounting for the specific transaction.

A wide variety of credit card rewards programmes exists in the South African market, each with unique terms, conditions and structures. For annual reporting periods beginning on or after 1 January 2017, IFRIC 13 will be withdrawn. IFRS 15 will replace IFRIC 13, an Interpretation credit card rewards programmes would have applied for almost nine years up until the effective date of IFRS 15. Credit card rewards programmes will need to consider and determine whether their rewards programme falls within the scope of IFRS 15 and, if not, what other Standard(s) should 
be applied in terms of accounting for credit card rewards programme transactions. If a credit card rewards programme concludes that its rewards programme falls within the scope of IFRS 15 , the credit card rewards programme must determine how to account for credit card rewards programme transactions given the minimum guidance contained in IFRS 15.

The research showed that one credit card rewards programme's view on the same type of rewards programme transaction may differ from the next, leading to credit card rewards programmes treating the same transaction differently for accounting purposes.

\subsection{Research objective and methodology}

The main objective of the research reported in this article was to develop and recommend an industry practice for the accounting treatment of South African credit card rewards programme transactions by reconciling the viewpoints of these rewards programmes. In order to meet the main objective, satisfactory answers to the following secondary questions first needed to be found:

- How does a credit card rewards programme function and are there different structures of credit card arrangements that will have an impact on the accounting treatment of these transactions?

- What is the current practice for accounting for credit card rewards programme transactions?

- What are the main areas of uncertainty identified based on the response to the $\varepsilon D / 2011 / 6$ ?

- What is the explanation of the logical reasons or principles employed in determining the customer in relation to the card issuer?

- What is the perspective of credit card rewards programmes in the South African market in regards to identifying the customer in relation to the card issuer and therefore determining whether or not their rewards programmes fall within or outside the scope of IFRS 15 ?

- Are there any accounting principles and practices applied by US GAAP that would be useful in this context?

The study made use of a qualitative approach based on a literature study of purely theoretical aspects. A document analysis was used as the research method. Hutchinson and Duncan (2012:101) describe the research strategy followed, which is doctrinal in nature, as research which provides a systematic exposition of the rules governing a particular topic. They further suggest an analysis of the relationships between rules, one that explains areas of difficulty and, perhaps, predicts future developments. The problem-based doctrinal research methodology applied in this research included the following steps (Hutchinson \& Duncan, 2012:106):

- Gathering of all relevant and applicable facts;

- Identification of the specific requirements;

- Analysis of the issues from a legislative perspective;

- Studying of sources such as academic text books and journal articles as background;

- The identification of primary sources of information;

- Synthesising of all the relevant issues within the correct context;

- The drawing of an effective and sensible conclusion.

The research showed that in the light of IFRS 15, uncertainty currently exists amongst IFRS compliers regarding the accounting treatment of credit card rewards programme transactions. In 
an attempt to determine the South African perspective on the accounting treatment of credit card rewards programme transactions it was decided, in addition to the above literature study, to obtain data using a survey (Hofstee, 2006:122). This factual information (Hofstee, 2006:122) can be applied in a comparative analysis (Hofstee, 2006:124). The literature review was therefore applied to develop a suitable questionnaire. The questionnaire was circulated to a population of credit card rewards programmes in South Africa. Twelve of the 13 credit card rewards programmes in the South African market were identified as the population for participation in the survey (refer to section 4: Credit card rewards programmes in the South African market). The questionnaire was aimed at determining whether or not credit card rewards programmes in the South African market are currently applying IFRIC 13 to account for their credit card rewards programme transactions and also whether credit card rewards programmes in the South African market believe their programmes fall within or outside the scope of IFRS 15. The questionnaire was circulated to this population of credit card rewards programmes. Of the 12 credit card rewards programmes selected, 11 valid responses were obtained. These 11 respondents, constituting a response rate of $92 \%$, were deemed representative of credit card rewards programmes in South Africa. The questionnaires were received and the data was processed. The responses indicated whether, and to what extent, South African credit card rewards programmes regard the accounting treatment of credit card rewards programme transactions as problematic.

To achieve the abovementioned objectives the article is structured as follows:

- Obtaining an understanding of the functioning and structures of credit card rewards programmes;

- Determining the current practice for accounting for credit card rewards programmes;

- Identifying the main problem areas or uncertainties associated with accounting for credit card rewards programmes under IFRS 15;

- A concise discussion on the different viewpoints of identifying the customer in relation to the card issuer;

- Facilitating communication between all South African credit card rewards programmes;

- Formulating a recommended industry practice for the accounting treatment of credit card rewards programmes in the South African market to ensure consistent accounting treatment across all industries;

- An international perspective on the accounting treatment of credit card rewards programmes with reference to US GAAP;

- Summary, conclusion and recommendations.

\subsection{Research contribution}

The research makes a contribution by providing specific guidance and clarity on the accounting treatment of credit card rewards programme transactions, taking into account the areas of uncertainty identified with the issue of IFRS 15. These guidelines will ensure consistency in accounting for credit card rewards programme transactions across all types of credit card rewards programmes in the South African market. The research highlighted important principles that will contribute to the body of knowledge to account for credit card rewards programme transactions. This information can be a useful tool in serving role players in the accounting environment. 


\section{STRUCTURE OF CREDIT CARD REWARDS PROGRAMMES}

The structure and the functioning of a credit card rewards programme will have a direct impact on the accounting treatment of these transactions. The study therefore started off with obtaining an in-depth knowledge of how these programmes function. A credit card rewards programme is part of a broad credit card arrangement that involves a network of parties and that, through various contracts, enables a cardholder to purchase goods or services on credit from merchants that accept that type of credit card (FASB \& IASB, 2013:2). There are different ways in which a credit card rewards programme can be structured. The two main structures that are typically used are an open loop structure and a closed loop structure.

\subsection{Open loop structure}

Open loop structures are multi-party structures and they operate through a system that typically connects two financial institutions, namely the issuing financial institution or issuer and the acquirer or merchant bank (Wikinvest, 2007). The open loop structure, the more popular structure of the two, is illustrated in FIGURE 1.

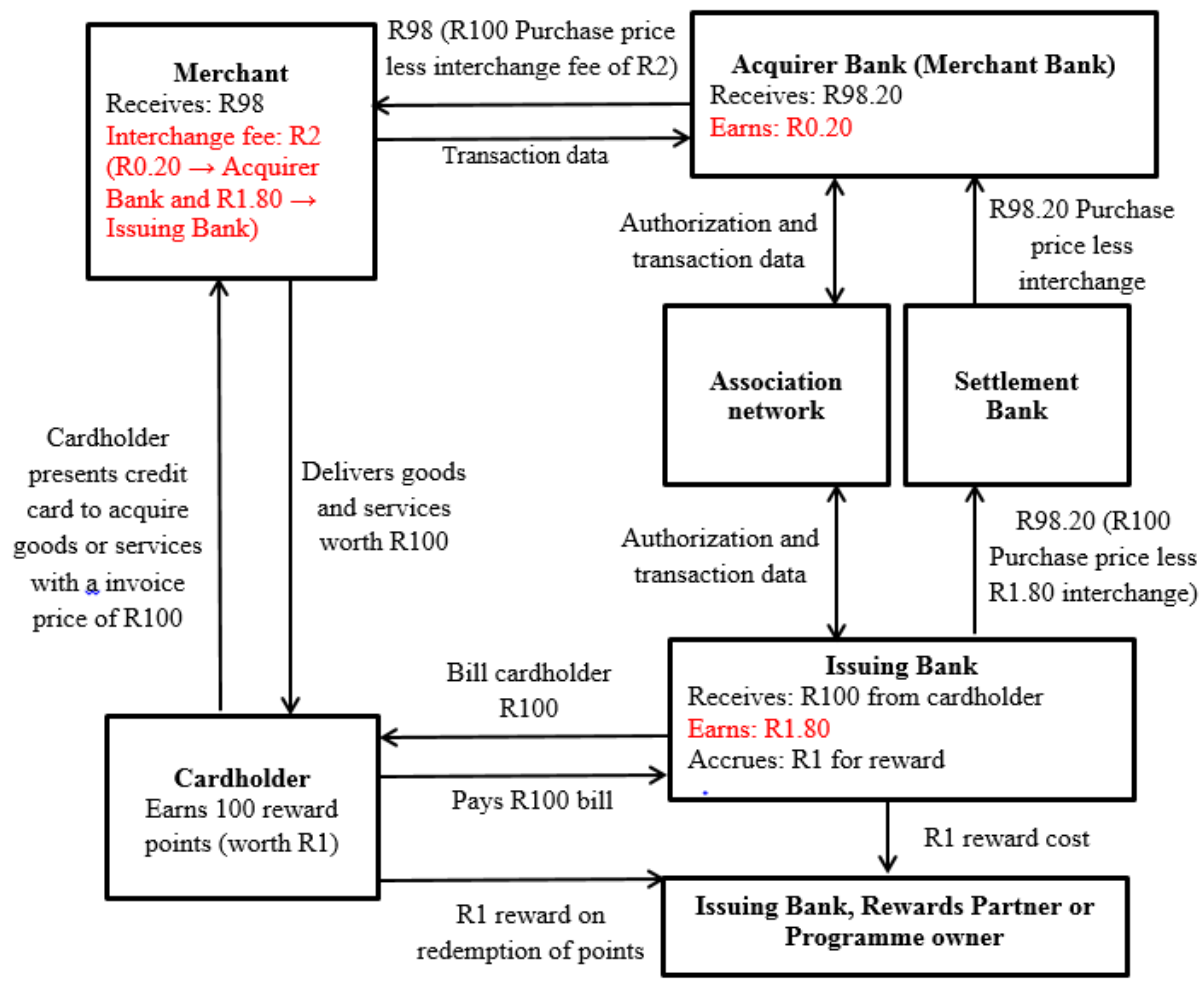

FIGURE 1: $\quad$ Open loop structure

Source: FASB \& IASB, 2013:3 
The issuing bank issues the credit card to the cardholder and the two parties enter into a contract, namely the cardholder contract. The cardholder contract governs the terms and conditions on the use of the credit card by the cardholder and includes the service fees, interest rates and payment schedules. The merchant enters into a separate contract with the acquirer or merchant bank. This contract, called the merchant contract, governs the terms and conditions under which the merchant will accept the use of a credit card in the sale of the merchant's goods or services (FASB \& IASB, 2013:3). The merchant contract includes the merchant interchange fees applicable (Wikinvest, 2007). The acquirer bank provides the merchant community with physical means for accepting the cards and receiving payment (Payments-R-Us, 2009). Under this structure the card issuer has no direct contract with the merchant (FASB \& IASB, 2013:4). The issuing bank and the acquirer bank are members of the association (Payments-R-Us, 2009). The association network consists of well-known credit card brands, such as Visa and MasterCard. These associations are responsible for creating and enforcing member-governing rules, providing and managing authorisation and settlement networks, monitoring fraud and enabling effective fraud controls, and mass marketing for their particular brand. The settlement bank takes charge of the settlement amount owed by a member of the bank (FASB \& IASB, 2013:3). In terms of the rewards programme, cardholders earn award credits (points or miles) from the card issuer when they use their credit card to make purchases from merchants (Ernst \& Young, 2013). The issuing bank, rewards partner or programme owner is responsible for supplying goods or services when a cardholder redeems his or her award credits (points) that were earned (FASB \& IASB, 2013:3).

\subsection{Closed loop structure}

Closed loop structures constitute a much smaller percentage of overall credit card transaction volume and are decidedly simpler than open loop structures. The fundamental difference in the closed loop structure is that the issuing bank and the acquirer bank are effectively one and the same.

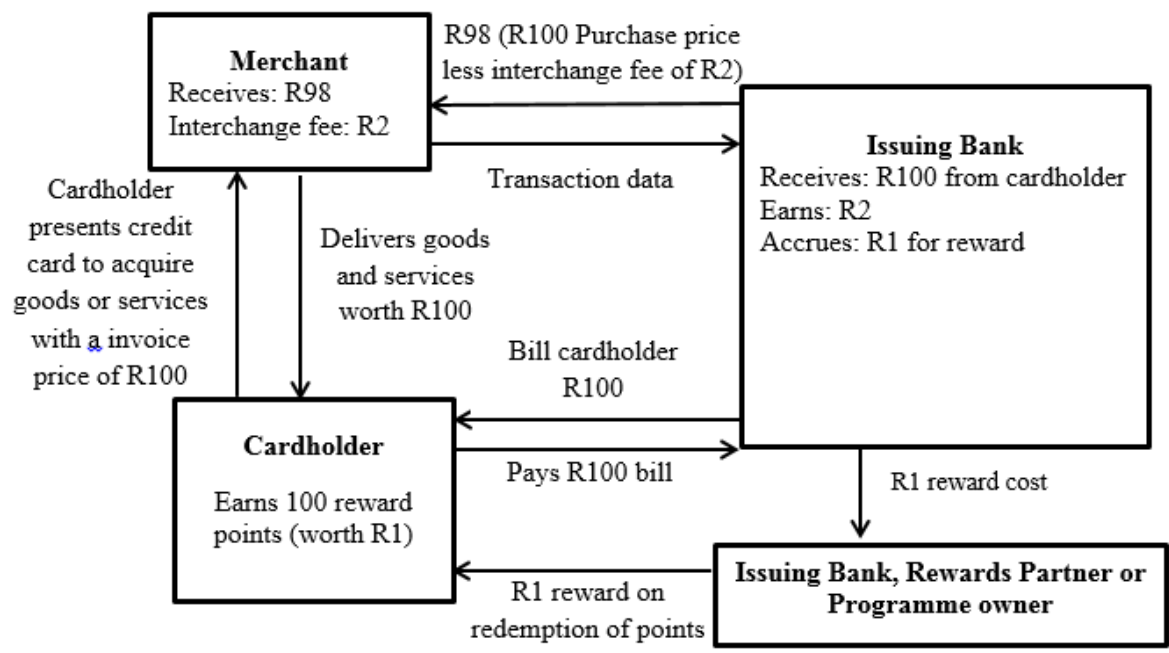

FIGURE 2: $\quad$ Closed loop structure

Source: Payments-R-Us, 2009 
Therefore, in a closed loop structure there is no independent organisation arbitrating between an issuer and an acquirer; there is no association present (Payments-R-Us, 2009). The issuing bank contracts directly with cardholders and merchants (Wikinvest, 2007). Examples of a closed loop structure are American Express and Discover (Payments-R-Us, 2009). The closed loop structure is illustrated in FIGURE 2.

\section{FUNCTIONING OF CREDIT CARD REWARDS PROGRAMMES}

In a typical credit card arrangement, when a cardholder purchases goods or services from the merchant, the merchant receives an amount of cash from the issuing bank (directly or through intermediary financial institutions) that is slightly less than the original invoiced price for the goods and services acquired by the cardholder. This difference between the invoice price and the cash paid to the merchant is referred to as the merchant interchange fee (FASB \& IASB, 2013:4). Card issuers can generate cash inflows from the merchant, namely the interchange fees, as well as from the cardholder, namely interest charged on outstanding credit card balances and annual service fees that entitle a cardholder to use a specific type of credit card (FASB \& IASB, 2013:5). Card issuers may also administer a credit card rewards programme as part of a credit card arrangement. In terms of the rewards programme, the cardholder receives award credits from the card issuer (credit card rewards programme supplier) for each credit card purchase transaction from a merchant (FASB \& IASB, 2013:4). The cardholder contract will include the terms and conditions of the rewards programme. Some credit card rewards programmes also charge a participation or linkage fee that enables the cardholder (member) to earn award credits in terms of the rewards programme (FASB \& IASB, 2013:12).

\section{CREDIT CARD REWARDS PROGRAMMES IN THE SOUTH AFRICAN MARKET}

There are currently 13 different credit card rewards programmes, each with unique terms and conditions, available in the South Africa market (Siddle, 2014). Only one of these credit card rewards programmes does not grant rewards based on every credit card purchase transaction from the issuing bank but only offers discounts on credit card purchase transactions from certain rewards partners. The rewards partners then allow the discount and the bank is not responsible for awarding any rewards. The remaining 12 credit card rewards programmes were therefore selected to form part of the population for the survey.

\section{METHOD OF ACCOUNTING}

\subsection{Existing guidance and current practice for accounting for credit card rewards programme transactions}

Before 1 July 2007 the IFRSs lacked specific guidance on how customer loyalty programmes should account for awards or benefits offered to customers in terms of these programmes. Based on a lack of specific guidance, practices diverged (IFRIC 13 Basis for Conclusions, par. BC 2) and customer loyalty programmes accounted for customer loyalty programme transactions differently. Based on this lack of guidance and the demand for specific guidance that was 
identified, the IASB issued IFRIC 13 on 1 July 2007 to give specific guidance to suppliers on the accounting treatment of customer loyalty programme transactions.

IFRIC 13 specifically includes credit card rewards programmes in its scope. IFRIC 13 Basis for Conclusions (that accompanies IFRIC 13) paragraph 4 states: 'In some sales transactions, the entity receives consideration from an intermediate party, rather than directly from the customer to whom it grants the award credits. For example, credit card providers may provide services and grant award credits to credit card holders but receive consideration for doing so from vendors accepting payment by credit card. Such transactions are within the scope of the Interpretation and the wording of the consensus has been drafted to accommodate them.'

In practice, most credit card issuers reporting under IFRSs account for rewards programmes under IFRIC 13 because of this inclusionary language contained in the Basis for Conclusions on IFRIC 13 (FASB \& IASB, 2013:7). Deloitte (2010:3) and KPMG (2007:1) also agree that credit card rewards programme transactions fall within the scope of IFRIC 13. KPMG (2007) explains how to account for a credit card rewards programme within the scope of IFRIC 13: credit card rewards programmes grant award credits to credit card holders with each credit card purchase transaction at third party vendors. The interchange fees that the credit card company receives for providing those credit facilities to the customer come indirectly from the customer via the fee that the vendor is required to pay to the credit card company. For accounting purposes, the vendor's fee or interchange fee can be identified as the revenue from the initial sales transaction which needs to be allocated by the credit card issuer between credit services supplied and the redemption of goods or services under the customer loyalty programme at a later date (KPMG, 2007:4).

Even though the scope of IFRIC 13 includes credit card rewards programmes, KPMG (2013) states that in practice not all credit card rewards programmes account for award credits under the revenue deferral model (IFRIC 13). Some financial institutions provide for the cost of satisfying the award credits (points or miles) as and when the customer earns them by recognising a provision (in terms of IAS 37 Provisions, Contingent Liabilities and Contingent Assets) and related expense. Instead of recognising an expense, other credit card issuers currently recognise the cost of reward credits as an offset to merchant interchange fee income when rewards are granted, and record a corresponding liability in terms of IAS 37 (PricewaterhouseCoopers, 2012:16)

The following example illustrates the three different accounting practices currently applied by IFRS compliers: A financial institution operates a rewards programme. It grants credit cardholders (members) award credits for all credit card purchases. In terms of the credit card arrangement, the merchant contract determines that the interchange fee per transaction amounts to $2 \%$ of the transaction value. In terms of the rewards programme the member earns one award credit for every R100 spent on the credit card. Each award credit is redeemable for a R0.10 discount on future purchases of goods or services offered by the financial institution (as displayed on their website). Assume that a member purchases goods from the merchant worth R100 and pays with his credit card. The merchant pays the financial institution the interchange fee of R2 (by only receiving the invoice price less the interchange fee from the issuing bank (directly or through intermediary financial institutions)). The financial institution grants the member one award credit worth R0.10. Assume that management calculates the fair value of one award credit as R0.10. The journal entries accounting for the interchange fee income in the financial institution offering the rewards programme for the three different accounting practices are illustrated in TABLE 1 . 
TABLE 1: General journal entries for the financial institution offering the rewards programme for the three different accounting practices

\begin{tabular}{|l|l|l|l|r|r|l|l|l|}
\hline \multicolumn{2}{|c|}{ IFRIC 13 } & \multicolumn{2}{l|}{ Provision and related expense } & \multicolumn{2}{c|}{$\begin{array}{l}\text { Offset to merchant } \\
\text { interchange fee income }\end{array}$} \\
\hline Dr. Bank & 2 & & Dr. Bank & 2 & & Dr. Bank & 2 & \\
\hline $\begin{array}{l}\text { Cr. Interchange } \\
\text { fee income }\end{array}$ & 1.90 & $\begin{array}{l}\text { Cr. Interchange } \\
\text { fee income }\end{array}$ & & 2 & $\begin{array}{l}\text { Cr. Interchange } \\
\text { fee income }\end{array}$ & 1.90 \\
\hline $\begin{array}{l}\text { Cr. Deferred } \\
\text { income }\end{array}$ & 0.10 & Dr. Expense & 0.10 & & Cr. Provision & 0.10 \\
\hline & & Cr. Provision & & 0.10 & & & \\
\hline
\end{tabular}

Source: Author's analysis

From the literature referred to in this section it is clear that although IFRIC 13 provides specific guidance, including credit card rewards programme in the scope of IFRIC 13, in practice credit card rewards programmes account for these transactions differently. These divergent practices make one question the accuracy of the current guidance provided in IFRIC 13 as well as the reason why credit card rewards programmes account for these transactions differently. Based on the aim of IFRS 15, namely to streamline accounting for revenue across all industries and to correct inconsistencies in existing Standards and practices, one would expect that inconsistencies like those mentioned above will be addressed. But the Boards' reaction to the queries, uncertainties and concerns raised in the response to the $\varepsilon D / 2011 / 6$ indicates the opposite. Credit card rewards programmes are left in the dark and it is expected that inconsistencies in accounting for credit card rewards programme transactions will continue and possibly increase.

\subsection{Uncertainties identified with the issue of IFRS 15}

The scope of IFRS 15 (paragraph 6) states that an entity shall apply IFRS 15 to a contract only if the counterparty to the contract is a customer. Therefore, in a credit card rewards programme transaction the customer in relation to the card issuer determines whether or not the rewards programme transaction falls within the scope of IFRS 15 or not.

In practice, and based on IFRIC 13's guidance, the interchange fee was identified as the revenue stream from the initial sales transaction that needs to be allocated to the goods or services sold and the award credits granted. If the interchange fee that the merchant pays represents consideration in exchange for a service provided by the card issuer to the merchant, then the merchant is identified as the customer in relation to the card issuer in the transaction. The transaction then falls outside of the scope of IFRS 15 and the award credits granted would be accounted for as a cost (FASB \& IASB, 2013:9).

If the interchange fee represents consideration in exchange for a service provided by the card issuer to the cardholder, then the cardholder is identified as the customer in relation to the card issuer in the transaction. The award credits granted to the cardholder would then be within the scope of IFRS 15. Accordingly the award credits would be accounted for as a separate performance obligation (unless they were in the form of cash, in which case they would be accounted for as consideration payable to a customer) (FASB \& IASB, 2013:10). 
Based on a lack of specific guidance or a response to the queries or concerns raised by respondents to the $E D / 2011 / 6$, the card issuer might determine that its customer is the merchant, while in other cases the card issuer might determine that its customer is the cardholder (FASB \& IASB, 2013:11). The staff of the IFRS Foundation and the FASB (the staff) believes that both views (identifying the merchant as the customer or identifying the cardholder as the customer) are possible and that both views can be substantiated with reasons for the conclusion. The staff explains the two views as follows:

View 1: The merchant is the card issuer's customer for the interchange service

With each credit card transaction at a merchant, the card issuer provides the merchant with the service of enabling the cardholder to purchase the merchant's goods or services with increased convenience, and it enables merchants to transact with a class of customer that may not have access to sufficient funds at the time of purchase. The card issuer therefore provides the merchant with a service of greater access to potential customers and in exchange charges the merchant an interchange fee (FASB \& IASB, 2013:17). In terms of the credit card rewards programme, the cardholder is granted award credits that give the cardholder a right to goods or services based on the amount of purchases they make in transactions with merchants. Proponents of this view argue that the award credits are granted by the card issuer as a reward for the interchange fee income generated from each credit card transaction. The cardholder therefore acts as a sales agent on behalf of the card issuer for the interchange service resulting in the interchange fee income. The award credits granted to the customer can thus be seen as a commission payment. Under this view, it can be argued that the award credits would not be within the scope of IFRS 15 . The award credits would be recognised as a cost of providing services when the obligation is incurred in accordance with the applicable IFRSS (FASB \& IASB, 2013:17). The following supports the view that the merchant is the customer in relation to the card issuer:

- The merchant bears the cost of the interchange service and therefore the merchant is the party who receives the service related to that cost. Proponents of this view also observe that some merchants try to pass on this interchange fee cost to the cardholder by charging the cardholder a higher price for a good or service when paid for by a credit card rather than cash. This further supports the fact that the merchant bears the cost of the interchange service, because, in some cases, the merchant passes that cost on to the cardholder (FASB \& IASB, 2013:18).

- There is a separate contract between the card issuer and the merchant (in the case of a closed loop structure) or between the acquirer bank and the merchant (in the case of an open loop structure) that outlines the terms and conditions for the arrangement (FASB \& IASB, 2013:17). The merchant contract will include the merchant interchange fees applicable (Wikinvest, 2007).

- The merchant contract's contractual promises will typically state that the services that will be provided to the merchant are transaction processing services (that is, the interchange service). Without these services there would be no rationale for the merchant to enter into a contractual arrangement with the card issuer (FASB \& IASB, 2013:18).

View 2: The cardholder is the card issuer's customer for the interchange service

When a credit card is used at a merchant, the card issuer provides the cardholder with two goods or services. The first service the card issuer provides is a loan enabling the cardholder to purchase the merchant's goods or services on credit, for which the card issuer will earn interest (a financial instrument transaction). The second service the card issuer provides to the cardholder is to 
electronically transfer the cash (obtained from the loan) to the merchant for the goods or services purchased on credit. According to this view, the second service is a separate service, because this service is often provided by the card issuer in other cases as well (such as debit cards where the loan portion of the arrangement will not exist) (FASB \& IASB, 2013:18-19). In exchange for providing the cardholder with a service of electronic transfer of funds, the card issuer earns an interchange fee from the cardholder (and not from the merchant as is the case in View 1). Proponents of this view believe that even though the cardholder does not pay the interchange fee directly to the card issuer, the cardholder indirectly pays for the interchange service by implicitly paying the merchant a higher price for the goods or services than they would otherwise have to pay (FASB \& IASB, 2013:19). In some cases the merchant will charge the cardholder a higher price if a credit card is used as opposed to cash, meaning that the cardholder bears the cost of the interchange service. In other cases the merchant is prepared to have the cost of the interchange fee passed on by the cardholder. In these cases, the merchant takes this cost into account when determining the selling price of the goods or services on a portfolio basis. In terms of the credit card rewards programme, the cardholder obtains goods or services from the card issuer in the form of the interchange service and the award credits that are granted (FASB \& IASB, 2013:19). Under this view, it can be argued that the award credits would be within the scope of IFRS 15, because the cardholder receives the award credits in his or her capacity as a customer (FASB \& IASB, 2013:19). The following supports the view that the cardholder is the customer in relation to the card issuer:

- The majority of credit card arrangements feature an open loop structure (refer to FIGURE 1). In an open loop structure the card issuer has a direct contractual relationship only with the cardholder and not with the merchant. The acquirer bank (and not the card issuer) has the direct contract with the merchant (as per FIGURE 1 ). If the card issuer has a direct contract with only the cardholder and the contract combination guidance does not apply, supporters of this view are of the opinion that the merchant cannot be the customer of the card issuer because in most cases (where an open loop structure exists) there is no direct contract between the card issuer and the merchant (FASB \& IASB, 2013:19).

- The cardholder is receiving the interchange service and the cardholder pays for this service by implicitly paying more for the goods or services from the merchant. Proponents of this view agree that some merchants (for example, petrol/gas stations) charge the cardholder a higher price for a good or service when paid for by a credit card rather than cash. They are of the opinion that this supports the fact that the cardholder bears the cost of the interchange service, because when the merchant charges a surcharge for the use of the credit card, the merchant is in effect explicitly acknowledging that the cardholder is paying for this service (FASB \& IASB, 2013:19).

- In a debit card arrangement the interchange fee obtained by the card issuer is significantly lower than in a credit card arrangement. Supporters of this view think that the relatively higher interchange fee for a credit card relates to the card issuer recovering their incremental costs (plus a margin) of providing credit-related services to the cardholder. Although those credit-related services might be linked to the loan portion of the arrangement, supporters of this view are of the opinion that it is still the cardholder (and not the merchant) who is the customer and who obtains the services in the arrangement (FASB \& IASB, 2013:19).

Based on the above it is also possible to argue for a combination of View 1 and View 2 resulting in identifying both the merchant and the cardholder as the card issuer's customer for the interchange fee. Both parties benefit from the bank's service: the merchant receives greater 
access to potential customers (possibly resulting in increased sales figures) and the cardholder receives the service of electronic payment facilitation. The bank therefore acts as an agent bringing two parties (the merchant and the cardholder) together to transact. If this is the case then a part of the transaction falls outside the scope of IFRS 15 and a part of the transaction falls within the scope of IFRS 15. Therefore, in theory a part of the interchange fee must be allocated to the award credits (under IFRS 15) and a part of the award credits must be accounted for as a cost.

\subsection{Impact of the two different views on identifying the customer in relation to the card issuer}

On the assumption that the interchange fee is correctly identified as the consideration received in the initial purchase transaction, it is clear from the above arguments that both views have merit and can be considered as correct. The introductory paragraph to the illustrative Example 52 (that accompanies IFRS 15) states that where multiple parties are involved in a customer loyalty programme an entity should consider all the facts and circumstances to determine the customer in the transaction that gives rise to the award credits (IFRS 15 par. IE249). With this the Boards are leaving it up to credit card rewards programmes to apply their own judgement in deciding whether their programme falls within the scope of IFRS 15 or not. Therefore in practice, based on a lack of specific guidance, credit card rewards programmes can either account for credit card rewards programme transactions in accordance with IFRS 15 or in accordance with other relevant Standards. The lack of guidance will lead to inconsistencies in the accounting for credit card rewards programme transactions between different financial services offering a rewards programme. These inconsistencies will prevent credit card rewards programmes from meeting one of the enhancing qualitative characteristics of financial information, namely comparability.

The Conceptual Framework sets out the concepts that underlie the preparation and presentation of financial statements. Financial statements are prepared for the purpose of providing information to existing and potential investors, lenders and other creditors that is useful in making economic decisions. These decisions include the buying, selling or holding of equity and debt instruments, and providing or settling loans and other forms of credit (Conceptual Framework for Financial Reporting, Chapter 1 par. OB2). Qualitative characteristics of financial information identify the types of information that are likely to be most useful for users of financial statements (Conceptual Framework for Financial Reporting, Chapter 3 par. ( CCl). One of the enhancing qualitative characteristics of financial information is comparability, and the usefulness of financial information is enhanced if it is comparable not only from one period to the next but also if it is comparable with similar information about other entities (Conceptual Framework for Financial Reporting, Chapter 3 par. (C4, (C20).

\section{FINDINGS BASED ON EMPIRICAL STUDY}

The responses provided in the questionnaires indicate the perspectives of credit card rewards programmes on the accounting treatment of credit card rewards programme transactions in the South African market. More specifically the responses indicate whether or not credit card rewards programmes in the South African market are currently applying IFRIC 13 to account for your credit card rewards programme transactions and also whether credit card rewards programmes in the South African market believe their programmes to fall within or outside the scope of IFRS 15. 


\subsection{Respondent profile}

From the total population of 12 credit card rewards programmes, 11 responses were obtained, constituting a response rate of $92 \%$.

\subsection{Current accounting treatment}

Respondents were required to indicate how they currently account for a credit card rewards programme transaction for accounting purposes. Nine of the 11 respondents $(82 \%)$ indicated that they currently apply IFRIC 13 to account for credit card rewards programme transactions. Only one credit card rewards programme (9\%) indicated that they apply IAS 37 Provisions, Contingent Liabilities and Contingent Assets by recognising a provision (and the related expense) for the award credits granted. The other credit card rewards programme, which grants direct cash back rewards, recognises a financial liability in terms of IAS 32 Financial Instruments: Presentation for the award credits granted. This response indicates that although the scope of IFRIC 13 includes credit card rewards programmes, not all South African credit card rewards programmes currently apply IFRIC 13. This is in line with what is evident among other IFRS compliers (internationally).

\subsection{Future accounting treatment}

The research sought to determine who the card issuer views as the customer for the interchange service and consequently whether or not the transaction is considered to fall within or outside the scope of IFRS 15. Rather than asking the card issuer to indicate who they regard as the customer and whether or not the transaction falls within or outside the scope of IFRS 15 it is perhaps better first to address the nature and extent of the underlying service rendered (i.e. the interchange service) that gives rise to the transaction. The service that is rendered for the interchange fee will determine the customer in relation to the card issuer and the customer in relation to the card issuer will determine whether or not the transaction falls within or outside the scope of IFRS 15. Therefore, determining what service is rendered in exchange for the interchange fee, and to whom, will ultimately answer the question of whether or not the transaction falls within or outside the scope of IFRS 15. The financial managers, the ones responsible for completing the questionnaire, will also have a much better understanding of how their business functions rather than the pure accounting treatment prescribed by IFRS. By focusing on what the interchange fee represents one should arrive at a clearer indication of how to ultimately treat the transaction for accounting purposes. Respondents were required to indicate what service is being rendered in exchange for the interchange fee and ultimately to whom. Seven of the 11 respondents $(64 \%)$ indicated that they believe that both the merchant (being provided with a service of greater access to potential customers) and the cardholder (being provided with a service of electronically transferring the cash to the merchant for the goods or services purchased on credit) are the customers for the interchange fee. Three of the 11 respondents (27\%) indicated that they view the cardholder as the customer for the interchange fee. The other credit card rewards programme (9\%) was not willing to share its thoughts on this question, because it had not yet considered IFRS 15.

Based on the responses obtained, the following conclusions can be made about South African credit card rewards programmes' perspective on credit card rewards programme transactions:

- Credit card rewards programme transactions fall within the scope of IFRS 15 (even if it is just a part of the transaction); 
- Credit card rewards programme transactions are viewed differently and this will result in different accounting treatment;

- There is still uncertainty about the accounting treatment of credit card rewards programme transactions in the light of the new revenue model.

\section{INTERNATIONAL PERSPECTIVE}

\subsection{An international perspective on the accounting treatment of credit card rewards programmes with reference to US GAAP}

In order to find accounting principles or practices that could be useful in the context of this research, the accounting treatment of credit card rewards programme transactions with reference to US GAAP was considered. There is no comprehensive guidance in US GAAP on how to account for credit card rewards programmes (KPMG, 2013). There is, however, specific guidance on the treatment of annual credit card fees. This guidance can be found in Subtopic 310-20 (formerly FAS 91, Accounting for Non-refundable Fees and Costs Associated with Originating or Acquiring Loans and Initial Direct Costs of Leases). Credit card fees are defined as 'the periodic uniform fees that entitle cardholders to use credit cards'. Fee income meets the definition of credit card fees and '[is] viewed in part as being loan commitment fees' and 'shall be deferred and recognised on a straight-line basis over the period the fee entitles the cardholder to use the card'. In practice, most card issuers reporting under US GAAP account for any annual credit card fees collected in accordance with Subtopic 310-20 (FASB \& IASB, 2013:6).

There is no specific guidance with respect to merchant interchange fees and rewards programmes under US GAAP. In practice, the staff of the IFRS Foundation and the FASB (the staff) understands that most card issuers reporting under US GAAP account for the interchange fee as revenue when the cardholder acquires goods or services on credit from merchants. At the same time, card issuers account for award credits by recognising an expense and accruing a liability in the amount of the cost expected to be incurred in fulfilling the award credits obligation. Some card issuers reporting under US GAAP present the interchange fee income net of the cost of the associated award credits while others recognise the interchange fee income and the cost of the associated award credits separately (FASB \& IASB, 2013:6). This accounting treatment is the same as that applied by some credit card rewards programmes under IFRS to account for their rewards programme transactions (refer to 5.1 Existing guidance and current practice for accounting for credit card rewards programme transactions).

\section{CONCLUSION AND RECOMMENDATIONS}

For annual reporting periods beginning on or after 1 January 2017 IFRIC 13 will be withdrawn and replaced by IFRS 15. Although IFRIC 13 includes credit card rewards programme transactions in its scope, not all IFRS compliers (including South African compliers) apply IFRIC 13 in accounting for credit card rewards programme transactions, indicating that the existing guidance is insufficient to ensure consistent accounting treatment. One would expect that the Boards addressed these inconsistencies in IFRS 15, but based on their response, leaving it up to management's judgement to determine how to account for credit card rewards programme transactions, the opposite is indicated. The biggest uncertainty considering the new revenue model pertains to identifying the 
customer in relation to the card issuer and ultimately determining whether or not credit card rewards programmes fall within the scope of IFRS 15 or not. There are arguments for identifying the cardholder and/or the merchant as the customer in relation to the card issuer and both views have merit and can be considered as correct. Therefore credit card rewards programmes can either account for credit card rewards programme transactions in accordance with IFRS 15 or in accordance with other relevant Standards, or a combination of the two. The majority (64\%) of South African credit card rewards programmes identified both the merchant and the cardholder as the customers for the interchange fee. It is therefore recommended, as an industry practice, that all South African credit card rewards programmes allocate a part of the interchange fee to the award credits granted (under IFRS 15) and recognise a cost for the remaining part of the award credits granted. This will ensure consistent accounting treatment of credit card rewards programme transactions in South Africa.

\section{The following areas are recommended for further study}

Although IFRIC 13 provides specific guidance on accounting for credit card rewards programmes transactions, by including credit card rewards programmes transactions within the scope of IFRIC 13 , in practice, credit card rewards programmes account for these transactions differently. Some credit card rewards programmes account for award credits under the revenue deferral model (IFRIC 13), some account for the cost of satisfying the award credits (points or miles) as and when the customer earns them by recognising a provision (in terms of IAS 37) and related expense, and others recognise the cost of reward credits as an offset to merchant interchange fee income when rewards are granted, and record a corresponding liability in terms of IAS 37 (PricewaterhouseCoopers, 2012:16). These divergent practices cause one to question the accuracy of the current guidance provided in IFRIC 13 and to ask what the reason is behind credit card rewards programmes accounting for these transactions differently. The Accounting Treatment of Credit Card Rewards Programmes Part 2 will investigate whether credit card rewards programmes should have been included in the scope of IFRIC 13. The article will examine the differences between a typical customer loyalty programme and a credit card rewards programme in order to shed some light on the rationale why credit card rewards programmes should perhaps be treated differently for accounting purposes. The correctness of identifying the interchange fee as the revenue stream from the initial sales transaction that needs to be allocated to the goods or services sold and the award credits granted will also be considered and discussed. If it is found that credit card rewards programmes should fall outside the scope of IFRS 15 this article will explain what other Standard(s) should be applied for accounting for credit card rewards programme transactions. Based on the introductory paragraph to the illustrative Example 52, which states that where multiple parties are involved in a customer loyalty programme an entity should consider all the facts and circumstances to determine the customer in the transaction that gives rise to the award credits (IFRS 15 par. IE249), the Boards are leaving it up to credit card rewards programmes to apply their own judgement in deciding whether their programme falls within the scope of IFRS 15 or not. Therefore, theoretically a credit card rewards programme can view its transaction within the scope of IFRS 15 and if this is the case the credit card rewards programme needs to determine how to apply IFRS 15 to the credit card rewards programme transaction, given the minimum guidance provided and the unanswered uncertainties raised in the response to the $\varepsilon D / 2011 / 6$. The main objective of The Accounting Treatment of Credit Card Rewards Programmes Part 3 will be to determine how to account for a credit card rewards programme's transactions within the scope of IFRS 15 through the formulation of specific guidelines and to specifically address the uncertainties raised in the response to the $\varepsilon D / 2011 / 6$. 
The study will aim at assisting credit card rewards programmes in converting from IFRIC 13 to IFRS 15 by highlighting the differences between the requirements contained in IFRIC 13 and IFRS 15 .

\section{LIST OF REFERENCES}

Buchi, J. (2014). Rewards Credit Card - Definition of Rewards Credit Card. Available at: http://operationstech.about.com/od/glossary/g/RewardsCrCard.htm [Accessed 25 June 2014].

Conceptual Framework for Financial Reporting. (2010). International Accounting Standards Board (IASB). London.

Conradie, B. \& Goldstuck, A. (2003). Value in loyalty programmes 2003: A survey of South African rewards-based loyalty programmes. Razor's Edge Business Intelligence World Wide Worx.

Conradie, B. (2007). Value in loyalty programmes 2007: A survey of South African rewards-based loyalty programmes. Razor's Edge Business Intelligence.

Creditor Web. (2014). Rewards Program. Available at:

http://www.creditorweb.com/definition/rewards-program.html [Accessed: 25 June 2014].

Deloitte. (2010). IFRS News/etter: Customer loyalty programme. Available at:

http://www.deloitte.com/assets/DcomPoland/Local\%20Assets/Documents/Newslettery/Biuletyn\%2 OMSSF/pI_IFRS_Newsletter_2010.03.pdf [Accessed: 11 May 2012].

Deloitte. (2012). Retail \& Distribution Spotlight: How the Converged Revenue Recognition Model May Affect Sales Targets. Available at: http://www.deloitte.com/assets/Dcom-

UnitedStates/Local\%20Assets/Documents/AERS/ASC/us_aers_RDspotlight_0611.pdf [Accessed:

5 June 2012].

Ernst \& Young. (2012). The revised revenue recognition proposal - retail and consumer products. Available at:

http://www.ey.com/Publication/vwLUAssets/Applying_IFRS_in_Retail_and_Consumer_Products/\$FI LE/Applying\%20IFRS\%20\%20Revenue\%20recognition\%20proposal_retail\%20and\%20consumer\%20pr oducts.pdf [Accessed: 5 June 2012].

Ernst \& Young. (2013). Revenue recognition for credit card rewards and in-substance real

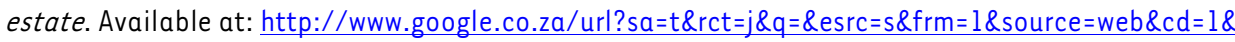
ved=0CDoPFjAA\&url=http\%3A\%2F\%2Fwww.ey.com\%2Fpublication\%2Fvwluassetsdld\%2Ftothepoint_b b2545_revenueredeliberations_29may2013\%2F\%24file\%2Ftothepoint_bb2545_revenueredeliberatio ns_29may2013.pdf\%3FOpenElement\&ei=GdoBU8WwFYa_yw0U9YCoAw\&usg=AFQjCNHX4W0zUa10_wd65 cKj0zrzKsSMKw\&bvm=bv.61535280,d.bGQ [Accessed: 17 February 2014]

$\varepsilon D / 2011 / 6$, Revenue from Contracts with Customers. (2011). International Accounting Standards Board (IASB). London.

FASB \& IASB. (2013). IFRS Staff paper FASB IASB Meeting. Available at:

http://www.ifrs.org/Meetings/MeetingDocs/IASB/2013/May/07A-Revenue\%20Recognition.pdf

[Accessed: 6 February 2014].

Firstrand Group. (2013). Firstrand Group Annual financial statements. Available at:

http://www.firstrand.co.za/InvestorCentre/FirstRand\%20Bank\%20Limited\%20Annual\%20Reports\%2 02012/2013\%20FSR\%20annual\%20integrated\%20report.pdf [Accessed: 29 April 2014].

Hofstee, દ. (2006). Constructing a good dissertation. Johannesburg: EPE. 
Hutchinson, T. \& Duncan, N. (2012). Defining and describing what we do: Doctrinal legal research. Deakin Law Review, 17(1): 83-119.

IASB. (2014). Workplan for IFRSs. Available at: http://www.ifrs.org/Current-Projects/IASBProjects/Pages/IASB-Work-Plan.aspx [Accessed: 13 May 2014]

IFRIC 13, Customer Loyalty Programmes. (2007). International Accounting Standards Board (IASB). London.

IFRS 15, Revenue from Contracts with Customers. (2014). International Accounting Standards Board (IASB). London.

Kearney, L. (2013). It's raining rewards. Available at: http://www.iol.co.za/business/personalfinance/it-s-raining-rewards-1.1551488 [Accessed: 17 April 2014].

KPMG. (2007). Financial Reporting Update. Available at: https://www.kpmg.com/CN/en/IssuesAndln sights/ArticlesPublications/Newsletters/Financial-Reporting-Update/Documents/FinancialReporting-Update-0712-38.pdf [Accessed: 20 June 2014].

KPMG. (2011). New on the horizon: Revenue from contracts with customers. Available at: http://www.kpmg.com/Global/en/IssuesAndlnsights/ArticlesPublications/N ew-on-the-Horizon/Documents/NOTH-revenue-from-contracts-a.pdf [Accessed: 19 February 2014].

KPMG. (2013). Defining Issues Revenue recognition: Credit card rewards programmes and Transfer of Nonfinancial Assets. Available at:

http://www.kpmg.com/CN/en/IssuesAndInsights/ArticlesPublications/Newsletters/DefiningIssues/Documents/Defining-Issues-0-1305-25.pdf [Accessed: 6 February 2014].

Lamoreaux, MG. (2012). A new system for recognizing revenue. Journal of Accountancy 213.1 (Jan 2012): $30-35,10$.

Payments-R-Us. (2009). Credit Card Systems and their Participants. Available at: http://www.paymentsrus.com/additional-articles/credit-card [Accessed: 7 February 2014].

PricewaterhouseCoopers. (2012). Practical guide to IFRS: Revenue from contracts with customers: Responses to re-exposed proposa/s. Available at: https://www.google.co.za/?gws_rd=cr\&ei=oVwDUTTleTNygP0q4DoBg\#q=Practical+guide+to+IFRS+Revenue+from+contracts+with+customers+pwc [Accessed: 18 February 2014]

Siddle R (ros@truth.co.za). April 2014. RE: Credit card rewards programmes. Email to author.

Wikinvest. (2007). Open-Loop versus Closed-Loop Payments Networks. Available at: http://www.wikinvest.com/stock/Visa_(V)/Open-loop_Versus_Closedloop_Payments_Networks [Accessed: 2 July 2014]. 